\title{
Islamic Jurisprudence and Unity of Nigeria: A Socio-Historical Reconsideration
}

\author{
Kingsley Okoro \\ Department of Philosophy and Religion, Ebonyi State University, Abakaliki, Nigeria \\ Email: okoro_kingsleyn@yahoo.com
}

How to cite this paper: Okoro, K. (2017) Islamic Jurisprudence and Unity of Nigeria: A Socio-Historical Reconsideration. Open Journal of Philosophy, 7, 467-483. https://doi.org/10.4236/ojpp.2017.74025

Received: July 31, 2017

Accepted: October 23, 2017

Published: October 26, 2017

Copyright (C) 2017 by author and Scientific Research Publishing Inc. This work is licensed under the Creative Commons Attribution-NonCommercial International License (CC BY-NC 4.0). http://creativecommons.org/licenses/by-nc/4.0/

\begin{abstract}
Nigeria's journey into nationhood has been steely as it has encountered several horrendous setbacks. The journey started with the amalgamation of 1914 . Since then, the uniting groups have engaged themselves in competition for dominance, instead of dialoguing for true unity/union which is necessary for nation building. This has resulted in internecine wars, conflict and crises, in several reins of the country's life. However with more than one hundred years of this marriage, it is therefore necessary to recast our journey. In recasting this history, we shall call to mind that: 1) The Nigeria foremost nationalists dreamt and laboured to make this country a great nation; 2 ) it is in the quest for this unity that the civil war of 1967-70 was fought; 3) Nigeria is founded on secularity/secular state ideality. Therefore, it is now time to redefine the basis for this unity, noting that great nations have heterogeneous formations, suggesting that our heterogeneity is not truly a weakness to our nation building goal. Therefore, to hide under the ambit of religion or ethnic myopism to scuttle the labours of our heroes past can never stand the test of quality logic. Hence the introduction and implementations of Sharia as alternative legal code in Nigeria are major steps towards disintegration. This work in adopting socio-historical method of investigation, affirms that the secular state of Nigeria and its maintenance must be given supreme consideration in Nigerian agenda, if she must attain her desired nationhood.
\end{abstract}

\section{Keywords}

Islamic, Jurisprudence, Nigeria, Socio-Historical, Reconsiderations

\section{Introduction}

Nigeria, an artificial creation of Luggard has had serious chequered developmental history. Part of the reason for her development trauma is that she was 
never a homogeneous nation (see Madiebo, 1980: p. 17). Notably, the component ethnic nations that were miss-mate into one nation without their real consent began their journey into nationhood without knowing what they are looking for and without definite idea of what it means to be a nation. Therefore their heterogeneity that ought to be their strength became their weakness. Actually every great nation even in the contemporary period is built on a heterogeneous formation, like America, Great Britain, China etc. Therefore what defines a nation is not cultural sameness nor blood ties but ideology. A nation built upon ideological rather than biological relationship benefits from the cultural diversity of her heterogeneous union. Therefore if Nigeria had had a definite vision/ideology that underpin her nationhood, she would have benefited from the Islamic culture, Christian culture and African traditional culture and these would have made her one people, with different beliefs and values. As Eluwa, Ukagwu, Nwachukwu and Nwaubani (1988), observe that culture describes a people's way of life and this includes the people's language, their political and social organization, their beliefs and religion, their literature and art and Nigeria is a beneficiary of these cultural accretions (1). Notably, Nigeria's population is as diverse as it is large, with some 250 ethnic groups. Nigeria's three largest ethnic groups are: Hausa-Fulani (29 percent of the population), Yoruba (21 percent) and Igbo 18 percent).

The geopolitical distribution of the nation locates the Hausa-Fulani ethnic group in the Northern part of the country. Southern Nigeria which is more westernized and urbanized than the north hosts the Yoruba in the southwest and the Igbo in the southeast. It is estimated that about half of the Yorubas are Christian and half Muslim, though many maintain traditional beliefs, the Igbo in the southeast adopted Christianity as their official religion, though with serious admixture of their traditional religion. The Roman Catholics seem to be in majority and often wealthier and influential within the Igbo domain.

These different nations with diverse socio-religious, cultural and political orientations were brought together at the whims of British parliament in 1914. Under normal circumstances, the union would have brought the different people closer and provide a firm basis for establishing the closer cultural, social, religious, political, linguistic and economic ties among and between the uniting ethnic groups as this was essential for true union (see Madiebo, 1980: p. 17). However, the prevailing circumstances could show that Nigerian nation was founded upon ideological and economic faultiness. Hence Luggard, an imperial agent knew that if Nigeria is allowed to develop on sound ideological and economic foundations, the British crown would face economic threats and as such he implored a mechanism of divide-and-rule system of governance for the country (see Madiebo, 1980: p. 17). This system encouraged social apartheid as it emphasized the social and ethnic differences of the uniting groups. By this means Luggard implanted hatred, rivalry and competitions with domination character. This unhealthy political/ideological system mushroomed even after independence as ethnic tensions increased, deepened by the rift between the 
supposed poor north and the more prosperous south. However, after decades of military coups and military rule, free elections were held in 1999 that brought the country back on the road to democracy. The federal form of government and the re-location of her Federal capital seek to balance the three major ethnic groups-and subdue ethnic and regional conflict.

Pre-colonial state-religion relations among the disparate ethnic nationalities that now form the geographical entity called Nigeria took various forms. Whereas the traditional institutions of governance of some ethnic nationalities were an amalgam of political and religious authority, religion and its institutions were independent of political authority in some communities. Also, the incongruous system of colonial administration in the different regions allowed the Islamic caliphatorial system of governance in northern Nigeria to continue uninterrupted, while imposing a western secular system in the southern part of the country. This administrative contrast reinforced the pre-existing incompatibility in state-religion relations among the ethnic nationalities that were now integrated as one nation state (Isaac, 2014: pp. 311-399). That is to say, in northern Nigeria, the surrender to Dan Fodio's Jihad and the subsequent establishment of the Islamic caliphate, however, changed the complexion of state-religion relations in Hausa communities. From the pre-caliphate notion of religion as an activity, essentially within the family and personal realm, Islam became a state religion (Salamone, 2007: pp. 45-54).

Here, Salamone (2007), enunciates that the Sultan of Sokoto, superintended the 15 emirates of the caliphate and served as the caliph, a position that encompassed both political and religious authority. Based on the British faction that northern Nigeria was mainly Muslims, the colonial-government's system of indirect rule relied heavily on the Hausa-Fulani political cum religious establishment to maintain control of northern Nigeria (45-54). Islam, therefore, was not only strengthened during British colonialism as the controlling faith in these areas but was made an organ of the state/government. Ultimately, the cultural divergence among the uniting ethnic nationalities, which was reinforced by the colonial policy of governance, bred a culture of sustained conflict and struggle for superiority between religious and state institutions on one hand, and between the various religious groups inter se (Isaac, 2014: pp. 311-339). Again, Isaac (2014) asserts that contemporary state-religion relations in Nigeria are characterized by ill-defined boundaries. Whereas the Nigerian constitution has declared freedom of religion and apparently seeks to separate state affairs from the doctrinal meanings of religion, although the same constitution, most time creates and recognizes executive and judicial institutions with religious biases (311-339). However, the existence of multiple judicial systems based on secular, religious, and traditional jurisprudence, as well as multiple educational system based on secular and religious principles only serve the purpose of obfuscating the real character of a nation (such as Nigeria), whether secular or religious. In consequence therefore, Isaac (2014), observes thus:

The security ramifications of this conceptual uncertainty mean that religion 
is often instrumentalized for political and hubristic ends, thereby creating strong animosity among religious groups...The consequence of this dysfunctional configuration of state-religion relations is the persistence of religiously induced conflicts in the country since the early 1980s. The persistent struggle by Islamists in northern Nigeria to establish Sharia law governance has been a consistent source of conflict, hence radical and violent groups often take advantage of the predominant deference to sharia law and governance among northern Muslims to orchestrate their clandestine motives" (311-339).

Therefore, the introduction of sharia (criminal code based on Islamic law) in two northern states in 2000 provoked violence between Christians and Muslims and caused mayhem that led to the destruction of lives and property worth billions of Naira and made non-Muslims and non-indigenes flee for their safety, either to other states or outside the shores of Nigeria (see Human Rights Watch, 2008). In response, the Nigeria inter religious council (NIREC), under the aegis of the National Reconciliation Committee organized a series of dialogue-meetings with Muslims on the issue of Sharia imposition (see Idowu, 2005: p. 2). Unfortunately, these meetings did not yield any positive result as is evident in the fact that a few month after the meetings, there were sporadic religious crises in Kaduna, Kano, Sokoto, Bauchi, Borno, etc. More than 2000 Christians were killed and more than 50 churches were set on fire (see Afro News, 2008: p. 1). Consequently, the Boko Haram's campaign of terror in northern Nigeria, which is ostensibly founded on an Islamization agenda demonstrates the ramifications of this challenge as this group's violent activities have stretched the elasticity of national security and unity. Today, in the words of Oladokun (2015), "we are at a point in our co-existence as a nation where we have to ask really hard questions.

1) Are we all on the same journey of nationhood?

2) Do we have the same dreams and aspirations as a nation?

3) Are we agreed on the methodologies with which to accomplish these dreams and visions?

4) Can the age-old militaristic political hegemony of the Hausa-Fulani ever be assuaged or subordinated for the better good of Nigeria? Or is it too deeply ingrained in their DNA?

5) Can our ethnic, religious, and political aspirations ever be subordinated for the better good of Nigeria? Ultimately, collective answers to these questions will determine where and how far we may go as a nation" (1-4).

This paper is therefore poised to alert Nigerians of the eminent danger that awaits our future and unity as a nation, if religious sentiments and ethnic biases continue to eat and ravage our unity and peace.

\section{Nigerian Nationhood Ideology: An Inquest}

The federal republic of Nigeria covers an area of $923,768 \mathrm{sq} \cdot \mathrm{km}$ on the shores of 
the Gulf of Guinea and borders with Benin in the west, Chad and Cameroon in the east, and Niger in the north. Its coast in the south lies on this gulf of guinea in the Atlantic Ocean (see Nigerian constitution). The country is variously estimated at one hundred and sixty and one hundred and seventy million at present. It is the most populated country in Africa. Its population is extremely diverse with well over 250 ethnic groups, some numbering fewer than 10,000 people (see Library of Congress: Federal Research Division, 2008). The country has one of the largest populations of Youths in the world (CIA World Fact Book, 2014).

Notably, Ten ethnic groups including Hausa-Fulani, Yoruba, Igbo, Kanuri, Tiv, Edo, Nupe, Ibibio and Ijaw account for nearly eighty percent [80\%] of the total population. Most of its population is concentrated in the southern part of the country, as well as in the area of dense settlement around Kano in the North. However, between the South and North is a sparsely populated middle belt. This great country with great destiny has come along way and cut great edges in an attempt to becoming a great nation. Therefore the need to recast her journey into nationhood so far becomes a necessity.

Here, Nigeria came under the colonial rule of the Britain (United Kingdom) during the second half of the $19^{\text {th }}$ century and the first decade of the $20^{\text {th }}$ century, the United Kingdom conquered the territory of present-day Nigeria, except for the section of former German-controlled Kamerun in several stages. According to Eluwa, Ukagwu, Nwachukwu and Nwaubani (1988), "In 1900, Sir Frederick Lugard was appointed High commissioner of the protectorate of Northern Nigeria and between 1900 and 1903, he conquered and occupied the Sokoto caliphate. Part of Borno was also occupied" [201]. The occupation of the non-Muslim areas was much more lengthy and difficult, in particular Tiv land. By 1905, however, most of Northern Nigeria was virtually under British control. Lugard left Northern Nigeria to take up the governorship of Hong Kong. However, when he came back he set out the task of joining the Southern and Northern parts of Nigeria. To accomplish this, he moved his seat of power to Lagos, the capital of the colony and protectorate of southern Nigeria and amalgamated Southern and Northern Nigeria in 1914.

Notably, the amalgamation of 1914 brought together the diverse ethnic nationalities for the purpose of convenience in administration. This he did with executive fiat. This is underscored by the fact that the arrangement of colonialization of the different uniting components of Nigeria were made by treaty. In his smart administrative maneuver, Luggard retained the division between the two Nigeria as separate administrative units, Lugard and his officials' discouraged real union of the North and South. They emphasized the differences between the two Nigerian areas and encouraged the divisions that were to plague Nigerian politics in later years (Eluwa, Ukagwu, Nwachukwu and Nwaubani, 1988: p. 201). Nnoli (1978) notes that "in spite of the similarities across the various pre-colonial societies of Nigeria, certain differences among them have affected the social distance among their members. In the intensely competitive atmos- 
phere of colonialism, it could not be otherwise. Under pervasive emphasis on differences rather than similarities it was inevitable (107).

Nevertheless, a legislative council initially with limited African representation was created in 1922. Traditional native rulers, however, administered various authorities. In 1947, a federal system of government was established under a new constitution introduced by the British rulers. This system was based on three regions: Eastern, Western and Northern. The idea was to reconcile the regional and religious tensions as well as accommodate the interest of diverse ethnic groups: mainly the Igbo (in the east), the Yoruba (in the west) and the Hausa/Fulani (in the north).

Again, prior to independence, nationalists continued their demand for the extension of franchise and the holding of direct elections. This led to the abrogation of the 1947 constitution and the introduction of a ministerial government in 1951. The federation became self-governing in 1954. Among the key instigators for independence in the country were, Dr. Nnamdi Azikiwe (who under the NCNC party later became the premier. He later became the first senate president followed by Gen aguiyi Ironsi who served as the president of Nigeria from January 16-July 29, 1966) and Herbert Macaulay, leader of the national council for Nigeria and Cameroons (NCNC), an eastern region dominated party, Obafemi Awolowo (leader of the western based Action Group (AG) party) and Sir Ahmadu Bello and Sir Abubakar Tafawa Belewa of the Conservative Northern People's Congress (NPC).

Recalling the events of the struggle for and regaining of independence, Eluwa, Ukagwu, Nwachukwu and Nwaubani (1978) note:

The establishment of British rule in Nigeria did not occur without resistance from the people. In the early years of British occupation opposition came mostly from the traditional rulers. There were the chiefs and Obas in the western part of Nigeria, kings of various houses in the Delta states and elders and war leaders in the east of Nigeria. In northern Nigeria, the opposition was led by emirs in the Muslim areas and tribal chiefs in the non-Muslim ones. When, however, the British subdued these oppositions they took over the traditional authorities as allies in the colonial administration. As a result, these elites criticized and opposed the colonial regime. First the opposition was limited to particular localities. Later, however, Nigerians waged their struggle on a larger scale until finally it embraced the entire country. In fact, by 1920 there had grown up a small group of educated Africans, who had begun to think of themselves not as Yoruba, Igbo, or Efik but as Nigerians, they saw the Nigerian nation-to-be and fought to free its peoples from colonial injustice and finally from colonial rule. They were the early Nigerian nationalists, and it was them that fought against the colonial master until independence was won (232).

However, conflicting demands for autonomy and central government by the various political groupings compelled the British in 1954 to accommodate their 
conflicting demands. In this arrangement, there was to be a federal government, in conjunction with considerable regional autonomy. Specific powers were to be allocated to the federal government including defense, the police force, the terms of national trade, custom duties, finance and banking. Responsibility for other services in the area of health, agriculture, education and economic development was to be with the regions. The federation of Nigeria achieved independence on 1st October, 1960 and in 1963 adopted a republican constitution but elected to stay a member of the common wealth. The first republic was replaced by the military, which ruled for 13 years, the second republic lasted from 1979 to 1983 , followed by another 15 years of military rule. (see

https://www.britannica.com/place/Nigeria). Nigeria today is seemingly democratic state with their having been no military coups since 1999 .

At birth, the young nation (Nigeria) faced enormous challenges ranging from political to ethnic hostility. Such as in May, 1962 the first population census in independent Nigeria was held and it amounted to several controversies among the three major ethnic groups. Another was the Aburi accord which saw the Easterners clamoring for their own interpretation of an autonomous region, this led to the move for secession lead by Emeka Odumegwu Ojukwu; consequently, Biafra lunched into war against the federal government of Nigeria in 1967 and it lasted to 1970. However, in the end, the federal armies which were much more than a match for the Biafran forces won the day (see Eluwa, Ukagwu, Nwachukwu and Nwaubani, 1988: p. 155). Furthermore, Eluwa, Ukagwu, Nwachukwu and Nwaubani (1988), writes:

Just as the Biafrans won the admiration of Nigeria and the world for their courage in war, Nigeria won the admiration of the secessionists and the world for her generosity in victory. Biafran surrender was followed not by genocide but by general amnesty and a relief program mounted by the Federal Government. Only a few of the Biafran officers were imprisoned. Later they were released. Many Igbo people were reabsorbed into the federal administration while many who had left the North at the time of the massacres returned to their old places. Gowon's policy of reconciling the defeated secessionists with the rest of the nation was one of his greatest achievements. It did so much to save the young Nigerian nation and it was a model example of how to win the peace (155).

Now, one might ask the reason why this paper had to go through the pleasant but thorough work of recounting the history of the Nigerian nation at this point. The answer is this, there is need for us to reconsider how far we have come as a nation, the struggle of our hero's past, the unity in mind and spirit that lead to our independence as a nation, and then, how fast we are destroying our collective effort, heritage and identity as a people by allowing religious, political and economic sentiments and selfishness to destroy the unity in purpose and aspirations we had built. 


\section{Modern Islamic Jurisprudence in Perspective}

Hausa-land, or the land of those who speak the Hausa language as their mother tongue covers in the main large areas of northern Nigeria and part of present day republic of Niger (Nzomiwu, 1989: p. 64). Again, Nzomiwu (1989) observes that, "Islam came to Hausa-land in the second half of the $14^{\text {th }}$ century during the reign of Sarki Yaji Ali (1349-1385). During this period, Muslim merchants and missionaries from Wangarawa in the empire of Mali preached Islam in Kano. Yaji and many of his subjects accepted Islam and a mosque was built in Kano. Gradually, Islam spread to other Hausa states, Kastina was the last to accept Islam" (64). Okoro (2008) however enunciates a double route of Islamic entrance into northern Nigeria. In his own words

Islamic religion, just like Christianity is one of the missionary religions in Nigeria. The religion made her first entry into what is known today as Nigeria in the $11^{\text {th }}$ Century $\mathrm{AD}$ enroute the Kanem Bornu Empire and through kastina enroute Kano in the $14^{\text {th }}$ Century $\mathrm{AD}$, therefore Islam found her way into northern Nigeria through diverse missionary enterprise [215-231].

Again, Islam spread faster through Moslems, who were believed to possess mystic power. It was believed they could make rain in a period of prolonged drought, make the ruler win war and protect him and his family from witchcraft. Through such beliefs many local rulers came to embrace Islam (see Eluwa, Ukagwu, Nwachukwu and Nwaubani, 1988: p. 155).

The religion through her dual method of spread, which are either covenant or conquest or both have made her inroad into various part of the country including the Christian dominated areas of the south. The religion since her entrance has wield preponderant high political clout in the country (see Attahir \& Dunmoye, 1994: p. 11). Socio-political echelon the religion has attained in the country is simply because Hausa-Fulani ethnic group found their identity with the religion and the fact that the British administration in Nigeria had carefully crafted their administrative system in northern Nigeria to allay with any identity-related anxieties. Though their political hierarchy was defeated but not humiliated; peace with not only honor but advantage within the British framework was provided to the Fulani elite. The Fulani rulers were confirmed in their functions; Hausa was used as a language of administration; Christian missions were excluded from Islamic areas (Crawford, 1976: p. 274). Hence Eluwa, Ukagwu, Nwachukwu and Nwaubani (1988), argue that there were those who were out for a total victory of Islam over paganism. It was them that lead a jihad in Northern Nigeria in the nineteenth century. Hence, Nzomiwu (1989) explains that, Jihad means holy war declared with the objective of winning unbelievers (i.e., non-Muslims) over to Islam, or subduing and exterminating them in case they refuse to become Muslims (64).

It is worthy of note that this largest ethnic category in Nigeria, the Hausa/Fulani adopted language and religion as the main defining characteristics of 
their cultural amalgam (see Crawford, 1976: p. 274). Here, Islam is better understood as a system of social obligations and rights than a system of beliefs. These obligations are preserved in the Sharia. Literally the word Sharia connotes "the clear Path to be followed" but it is at times technically referred to as the cannon-law of Islam. Every aspect of Muslim life is more or less regulated by Sharia. It contains the mobility of Allah's commandments as revealed in the Quran and elaborated in the Hadith and sunna and interpreted by Ijma (Nzomiwu, 1989: p. 64). Etim (2010), further observes that Sharia as Islamic Canon law comprises code of conduct that regulates worship, morals and interpersonal relationship (103-113). Joseph Schacht maintains that "it is impossible to understand Islam without understanding Islamic law" (qtd. In Savory, 1976: pp. 54-60). The Sharia is the foundation and sustainer of Islamic society. In this direction, Etim (2010) asserts that the Sharia creates a system of duties that are not only religious and ethical but legal. It defines actions that are forbidden (haram), required (fard, wajib), recommended (mandub, Mustahabb) tolerated (mubah, Jaiz), and what is disliked or frowned upon (makruh) (103-113). Notably, just as Nzomiwu (1989) posits, "whereas the canon-law does not legislate on political and social matters but concerns itself mainly with the religious, moral, and ecclesial life of the faithful, the Sharia legislates also on social, political and economic life of the Muslims" (79). The content of the Sharia is generally classified into two principal sections - the religious law (the ibadat) and non-religious law (the Mu'amalat).

The former-the Ibadat-deals with the religious and ritual duties and the latter deals with the executive, judicial, economic and political activities. The ibadat deals with the five pillars (salat-prayer, fasting-Ramadan, Hajj-Pilgrimage, Zakat-alms-giving and the Jihad) (Nzomiwu, 1989: p. 79). The mu'amalat (Nonreligious laws) include the laws on Politics, Economics, Social life and Morals. Against this backdrop, Nzomiwu (1989), further asserts

Sharia contains definite teachings which form the basis of Islamic political theory. The Sharia recognized Allah as the sole legislator. Man has no power to make laws. As far as Islam is concerned, no government has any legislative power. The function of political rulers is not to make laws but to execute the divine-law as contained in the Sharia. In this sense Islam is a nomocracy, i.e. a state ruled by a divine law (79).

Hence, this notion or belief inherent in Muslim faithful has degenerated into religious fanaticism and also caused religious intolerance and violence arising from Islamic sects. Nnoli (1978), states that religious differences have a high potential for separating people from one another. Throughout history these differences have been the basis of tension, animosity, hostility, and even war (107). In this sense therefore, the Jihad or Holy war has been the umbrella or cover of which violent and blood sucking sects in Islam (such as the Boko Haram sect) has hidden to carry out inhuman action and bloodletting in modern Nigeria. Lamenting this phenomenal disaster, Nzomiwu (1989) decries the situation thus: 
The propagation of Islam is no doubt a religious duty of every true Muslim. Jihad is a war undertaken for the spread of Islam. Thus the Quran urges the Muslim: when the sacred months are over, then fight and slay the pagans wherever you find them, seize them, beleaguer them, and lie in wait for them in every stratagem (of war); But if they repent and establish regular prayers and practice regular charity, then open the way for them. "For God is oft-forgiving, most merciful" (9:5)… Any Muslim who dies in such a war would win a crown of martyrdom. Such people as the Quran attests are not really dead but "living in the presence of their Lord, their needs supplied, rejoicing in the bounty which God has given them" (3:169-170)

Therefore, in many villages, towns and countries where Muslims are in the majority there is always a tendency to regard non-Muslims as second-class citizens and this often leads to oppression and denial of civic rights to non-Muslims. In the case of Nigeria, Islamic sects have vowed with their life to Islamize the whole nation, believing it is in accordance with what has been written in the Quran, forgetting that Nigeria is a secular state and full implementation of Islamic jurisprudence in non-Muslim state would be a civic violation of the constitutional and natural law of non-Muslims. In affirmation Etim (2010), avers that Sharia can only be implemented in an Islamic state. "It is glaring that the contemporary situation where Sharia is implemented in non-Islamic states is an aberration ab-initio" (103-113).

Undoubtedly, the state of the Islamic jurisprudence in the Muslim world today is abysmal, especially in the absence of the basic human rights protections that are taken for granted in much of the developing world (such as Nigeria) (see http://www.iar-gwu.org/node/23). Many Muslims and Non-Muslims alike seem to believe that Sharia is incompatible with a modern and democratic human rights framework and as such the secular state of any nation should be reversed to square up the Islamic/sharia scheme.

\section{The Socio Historical Reconsideration of the Islamic Jurisprudence Vis a Vis Nigerian Unity}

Overtly, the most discordant issue in any sharia discourse is the fundamental issue of religious freedom in a world that has become a global village/single unitwith multiple religious and cultural beliefs. Hence the $21^{\text {st }}$ century citizen will not countenance the draconian religious principles typical of medieval age. Therefore, modern Islamic jurisprudence, with its insistence on theocratic system of government and avid neglect or rather aspersion on universal declaration on the Rights of man seems to be an insult to the sensibility of the man/world come of age (see Etim, 2010: pp. 103-113).

Notably, the fundamental Islamic faith does not accept any demarcation between religion and politics (Etim, 2010: pp. 103-113). As a religion with totalitarian principles, Islam is not only concerned with the spiritual, eschatological or transcendent goals of religion but more concerned and aspires to control the so- 
cio-political and economic realities of human existence. Charles (1976), notes that in Islamic law, the religious dimensions of existence encompasses the whole of life. In his own words,

For this reason all issues of social policy in Muslim countries are religious questions requiring to be examined in the light of tradition and religious teaching... the continual appeal to religion in matters that others would consider secular is another puzzling element in Islamic life for the uninitiated foreigner" (35).

In the same vein, Etim (2010) posits that there is a scholarly consensus that democracy as conceived by western political philosophy is incompatible with Islamic principles of governance (103-113). Simply put, Islam cannot accommodate the tenets of democracy. Al Faruqi (1991) on his own part argues that the ideal Islamic state cannot be described meaningfully as theocratic since according to him, no human can speak or act for God, rather it is a monocracy, where sovereignty belongs to the law that God has revealed. He states inter-ilia "The Islamic state is not limited to any given land or to the Muslims; nor may it be defined as one where Muslim exercise the power. Instead, it is where Islamic law is the referee and Islamic values the objective..." (14).

Therefore the conflictual nature of Islamic jurisprudence is noted from the fact that fundamentalist groups/individuals in Islamic states promote a medieval form of religious laws and ethics that cast the period before renaissance into a dark side of history as they give radical interpretations to Sharia and uphold same as superior to the secular state. It is this belief and practice that have inspired terrorist groups in Nigeria and most part of the world. This indeed is forcefully shaking the foundation of Nigeria unity/union]. Without considering the implications to the hard earned Nigerian union, some Muslims, who by chance or fate ascended the Nigeria power room have made conscious efforts at one time or the other to Islamize Nigeria through a number of programs (see Odey, 2000: p. 27). The first attempt was made by General Ibrahim Babangida in January 8, 1986, when he sent official delegation to Organization of Islamic Conference [OIC] with the intent of registering the country as a member, however with its public notice hell was let loose in every part of the country (see Eme, 2012: pp. 191-203). In reaction therefore, the government took a palliative measure to calm the nerves of the people by setting up a 20 man committee to investigate the consequence as well as the implications of Nigeria's full membership to OIC, however the report of the panel is yet to be made public (see Eme, 2012: pp. 191-203).

Twelve years after, in 1998, a Government spokesman told the GUARDIAN on Sunday that given Nigeria's formal membership of the OIC, fresh efforts were being made to register Nigeria as a member of the Islamic Development Bank (IDB). Nigeria had enrolled as a member of OIC in 1986 but its membership remained dormant following the uproar that greeted it (see Dickson, 1992: 1.2). However, before the fresh efforts at registering Nigeria with IDB, the govern- 
ment had reportedly reactivated Nigeria's membership of the OIC. This announcement was made by the then sultan of Sokoto, Alhaji Muhammadu Maccido at a meeting with the Roman Catholic pontiff; Pope John 11 during the Pope's visit to Nigeria in March 1998 (Dickson, 1998: pp. 1-2).

The first major religious crisis in Nigeria occurred in December 1980 when the Maitastine sect of Muslims struck, leaving a death toll of 4, 177 persons and an unquantifiable volume of property destruction, 1000 members of the group were arrested during the riot and two years later, precisely on October 1, 1982, president Shehu Shagari ordered their release under state pardon (Odey, 2000: p. 21). Four weeks later, the group struck again in Maiduguri. The way president Shehu Shagari handled the matter of the state pardon and the setting up of a special advisory Board on Islamic Affairs were seen as one of Government's covert attempts to Islamize Nigeria (Eme, 2012: pp. 191-203).

According to Odey (2000), "To supplant Christianity in the country and make room for Islam, Babangida embarked upon a rabid elimination process of Christians in key positions in his administration" (21). By the year 2000 AD, 12 states of the federation, all in the North, had adopted the sharia. The idea was not to promote law and order and reduce the incidence of crime and social vices "NO... What they were pursuing was the agenda to Islamize Nigeria. By implication, the imposition of sharia as the main legal system for the country overtly means the denying of non-Muslims their fundamental freedom" (Eme, 2012: pp. 191-203).

However, the revitalized implementation of the sharia and its expansion from the personal to criminal aspects in 12 northern states represents one of the most turbulent cases of public policies in the contemporary history of Nigeria (Suberu, 2001: p. 19). The Sharia controversy pitted Muslim populations, who believed that it is the pure law revealed by God, against southern, middle Belt, and northern Christians, who fear that the sharia movement will violate their rights and reduce them to second class citizens. The fear of the non-Muslim population in Nigeria has been justified by the rise and activities of the following Islamic sects in the country. The maitastine, Izala and MSS. Movements (Ibrahim, 1989: pp. 62-82) and most recently, the Boko Haram suicide bombers in the north east of the country.

This fear of the non-Muslims in Nigeria is further sustained by the recent activities of Boko haram sect noting that the sect adduced their reason for taking the nation by storm when they tell us that western education and the whole gamut of western influence is sinful and a vitiation on divine law/rule [the sharia]. They are therefore fighting to ensure that the roots of western education are uprooted and sent back to Europe and America where they came from. Secondly, the members of the sect tell us that they are not pleased with the secular status of Nigeria. They want Nigeria to become a religious state, where the tenets of Islam, particularly the Sharia would reign supreme. To achieve their aim, they wish to begin with the twelve states in the north, where the rule of sharia has virtually taken the place of the nation's constitution. Thirdly, they believe that anybody who is not a Muslim is an eye-sore to God. He is an infidel and should 
be converted or killed (see Odey, 2012: pp. 48-75).

In Odey's idea, the Boko Haram phenomenon is the one issue that has attracted the attention of every Nigerian whether in the far-North, far-South, far-West or far-East. We are all involved. According to him, the reason for the general trepidation is clear. The young men, who throw the bombs that have been killing their fellow Nigerians in cold-blood tell us that they have declared a jihad against infidels. Nevertheless, the trouble lies in the fact that the bombs, being animate and irrational objects grow wings and go awry once they are thrown. Each time they throw them anywhere to kill the infidels, the bomb do not stop somewhere mid-air to separate the infidels from the believers before doing the job they are sent to do (Odey, 2000: pp. 48-75).

As was recalled by Odey (2012), in spite of the spirited effort to turn Nigeria into a Muslim country, Nigerians, Christians and other non-Muslims voted for two Muslims as their president and vice president in 1993. But Ibrahim Babangida, who felt that for not belonging to the Hausa/Fulani ruling pedigree, Abiola was not a real Muslim, annulled the election which was considered free and fair. Chief Olusegun Obasanjo, a Christian, became the leader of Nigeria in 1999 to avert a looming danger that threatened the unity of the country after the June 12 , 1993 annulment of that free and fair election won by Abiola and his subsequent death in the hands of his tormentors (48-75). Today, we are learning our lessons from hard facts and bitter happenings. The greater part of the mayhem that has been inflicted on the nation by the members of the Boko Haram sect is caused by an attempt to live by the legacy of defeat, domination and Islamization inherited from the founding fathers of Northern hegemony.

Ethno-religious conflicts in Nigeria have produced dysfunctional effects on social integration and inter-group relations in Nigeria nation building process. Religious conflict reinforces division in the Nigerian state (see Ani, 2012: pp. 156-172) Odey (2012) buttressing the above argues that.

"The nation is over heated up. I recall that following the killings of many Igbos in Kaduna in February 2000 by our Muslim brothers, Chukwuemeka Odumegwu Ojukwu declared: "If the price of nationhood is regular bloodletting, then let us not be a nation"... For those who cared to know why he made such a statement, he explained: "What I am saying here as I stand before you is that we are tired of being threatened. No religion has the monopoly of violence. If for instance, you tell me about the jihad, know that we had our crusades too, and you did not fare better"... The stage for the disintegration of Nigeria has long been set. The political, ethnic and religious atmosphere in the country has long been charged. The country itself has been sinking under the weight of the plethora of problems that have besieged it (48-75).

Now, the introduction of the sharia in some states of the country promoted religious intolerance that is still being witnessed till date. Religious intolerance has manifested itself as a deliberate and violent move to stamp out what Muslims 
believe to be an error in their religious thought and practices. This error is the presence of other religions within Nigerian religious environment (see Ani, 2012: pp. 156-172). Furthermore, Ani (2012) also notes that, "it is the blind refusal to study and observe as well as respect the view and tenets of other religions that has caused serious crack on the foundation of Nigerian unity vis-à-vis nationhood (156-172). It is pertinent to note that this act of implementing sharia, regarded by Muslims as divine law that superseded the secular laws/ constitution of the Nigerian state (in the view of many people from those sharia complaint states), that forced many of the non-Muslims in those states to leave en-masse to other parts of the country they assumed the "sharia trap" would not catch them easily (see Ani, 2012: pp. 156-172).

With all these repellant experiences, It looks like a miracle that the country has continued to exist as a corporate political entity (Odey, 2012: pp. 48-75). What can we do to avert the looming collapse of the staggering giant called Nigeria? Can we not be honest enough in this country to tell ourselves some bitter truths and then put an end to the unrelenting bloodshed and eventual disintegration of Nigeria? Can we not be honest enough to accept the fact that the current problem with Nigeria is that some of us have over blown our ethnic pride, carried our religious intolerance too far and fanatically demonstrated our lust to keep ruling and dominating others to the point that the centre can no longer hold?

Nevertheless, it is worthy of note that the nature of nation building process in both modern and traditional societies is dependent on the social relations between man, groups, the society and the environment. The quest for improved social relation was dependent on the fact that "whatever Africans share, we do not have a common traditional culture, common language as well as common religious or conceptual vocabulary (see Appiah, 1992: p. 1). Under such situation of cultural and religious differences, scholars have shown that inter-dependence becomes a major feature of societal relations (see Cohen, 1994: p. 12). However; just as Augustine (2003) argues, the greatest challenge to the world community in this century is how to promote harmonious relations between peoples of disparate histories, languages and religions, who find themselves intertwined in a single nation state (1-5). Hence, ethno-religious conflicts in Nigeria are the bedrock of social disintegration and failure in Nigeria nation building process. To be back on track on our journey of nationhood, Nigeria as a democratic society should not tolerate any part or a section of the country to be governed with an alternative/different legal code, be it religious or secular apart from the constitution of the Federal Republic of Nigeria

\section{Conclusions}

It was clear at Nigeria's independence in 1960 that the spirit of nationalism and togetherness was presented by the founding fathers as the driving force for the struggle to make Nigeria and her citizens self-reliant and free. But the ensuing 
crisis of the post-independence era, beginning with the enthronement of regionalism, tribalism, ethnicism, and partisan politics quickly eroded our virtues and values such as our brothers-keeper spirit, love, peace, compassion, solidarity and devotion to Nigerian state as enshrined in our national pledge and anthem. The civil war could be summarily described as "a war against the disintegration of Nigeria". In this war, much blood, more especially of the easterners was spilled to keep and foster Nigerian unity. Therefore, the blood of these Nigerians should, if for no other thing cement the desired unity. Therefore Nigeria and Nigerians require no more blood sacrifice for the atonement for unity and any more may be most damaging to the hard earned unity.

Thus the greatest harm to the nation presently is the consistent use of religious sentiments to destroy the remaining strings of the nation's unity and cohesion as observable in the callous destructive tendencies of the Islamist sect called Boko Haram (Isidore, 2012: pp. 33-47). From a holistic perspective, the adoption of sharia appears to contradict article 10 of Nigerian constitution that proscribes any state religion. This is especially as the constitution does not only declare the secularity of the Nigerian state but in section 1 (13) it also affirms the supremacy of the federal constitution over "any other law (that) is inconsistent with it. (Agbiboa, 2015)". Any nation, desirous of development in the right direction, unity must be at her behest. Ikegbu (2010) therefore suggests that to achieve national development and unity, citizens should deemphasize their differences, while emphasizing their similarities. In that way, ethnicity, tribalism, religious extremism, discrimination, hatred etc. will be eliminated (119-126). Our Muslim brothers in the north should accept and embrace in good fate the fact that Islamic jurisprudence cannot function in a secular state like Nigeria. Therefore, Boko Haram in its present form cannot be an alternative in Nigeria. Whether we are Christians or non-Christians, literates or illiterates, in school or out of school, working or not working, rich or poor, we must first learn to ignore our differences (Ikegbu, 2010: pp. 119-126). Finally the imposition of Islamic jurisprudence on Christians and non-Christians and in a secular state such as Nigeria is a violation of human right and a threat to the unity of this great country-Nigeria.

\section{References}

(2014). CIA World Fact Book.

Afro News (2008). Situations of Religious Freedom Deterioration in Nigeria.

Agbiboa, D. (2015). Sharia and the Nigerian Constitution: Strange Bed Fellows?

Al faruqi, S. (1991). Humanism and the Law: The case of the Sharia. Nigerian Institute of Advanced Legal Studies, 14.

Ani, K. (2012). The Impact of Religious Conflict on Inter-Group Relations in Nigeria. In O. Simon \& U. N. Isidore (Eds.), Boko Haram and Terrorism: Religious Conflicts and Dialogue initiatives in Nigeria (Vol. 2, pp. 156-172). Enugu: Snaap Press,.

Appiah, A. K. (1992). In My Father's House. In K. K. Prah (Ed.), Changing Solidarities, Ethnicity, Nationality and the Search for Democracy and Development in Africa. Lon- 
don.

Attahir, A. R., \& Dunmoye, R. A. (1994). Democratization and the Legacy of Pre-colonial Mode of Social Mobilization: A Focus on Islam and Consciousness. In Omoruniyi, Schlesser, Sambo \& Okwuosa (Eds.), Sokoto Caliphate' Democratization in Africa: Nigeria Perspective Vol. 1. Benin: Hima and Hima publishers

Augustine, J. (2003). An Opening Address Delivered at a Conference on Aboriginal and Diversity Law Enforcement Respect in Service. Winnipeg, Manitoba, June 5.

Charles, A. (1976). Islamic Faith: An Introduction to Islamic Civilization. In R. M. Savory (Ed.), Studies in Islamic History in Nigeria. Cambridge: Cambridge UP.

Cohen, A. (1994). Urban Ethnicity. London: Tavistock.

Crawford, Y. (1976). The Politics of Cultural Pluralism. London: The University of Wisconsin Press.

Dickson, A. (1998). Nigeria to Join Islamic Bank (pp. 1-2). Lagos: The Guardian.

Eluwa, G. I., Ukagwu, M. O., Nwachukwu, J. U., \& Nwaubani, A. C. (1988). A History of Nigeria: For Schools and Colleges. Onitsha: Africana First Publishers.

Eme, K. U. (2012). Government as Fuel for Religious Crisis in Nigeria. In O. Simon, \& U. N. Isidore (Eds.), Boko Haram and Terrorism: Religious Conflicts and Dialogue Initiatives in Nigeria (Vol. 2, pp. 191-203). Enugu: Snaap Press.

Etim, E. O. (2010). Islamic Jurisprudence and the Primacy of Sharia. African Journal of Religion, Culture and Society, 2, 103-113.

Human Rights Watch, Nigeria (2008). The Miss World Riots: Continued Impunity for the Killings in Kaduna. http://www.hrw.org/reports/2003/nigeria0703/2.htm

Ibrahim, J. (1989). The Politics of Religion in Nigeria: The Parameters of the 1987 Crisis in Kaduna State. Review of African Political Economy, 45, 65-82. https://doi.org/10.1080/03056248908703826

Idowu, F. J. (2005). Conflict and Cooperation between Christians and Muslims in Nigeria. The 4th Borderlands Lecture (Unpublished Lecture) at St John's College Durham.

Ikegbu, E. A. (2010). Unity and National Development in Nigeria. African Journal of Religion, Culture and Society, 2, 119-126.

Isaac, T. S. (2014). Religion and the Nigerian State: Situating the de facto and de jure Frontiers of State-Religion Relations and Its Implications for National Security. Oxford Journal of Law and Religion, 3, 311-339. http://www.oxfordjournals.org/page/5816/7 https://doi.org/10.1093/ojlr/rwt026

Isidore, U. N. (2012). Boko Haram and Violence Halal (A Reversion of Values). In S. O. Anyanwu, \& I. U. Nwanaju (Eds.), Boko Haram and Terrorism: Religious Conflicts and Dialogue Initiatives in Nigeria (Vol. 2, pp. 33-47). Enugu: Snaap Press.

Library of Congress (2008). Federal Research Division.

Madiebo, A. (1980). The Nigerian Revolution and Biafra War. Enugu: Fourth Dimension.

Nnoli, O. (1978). Ethnic Politics in Nigeria. Enugu: Fourth Dimension Publishers.

Nzomiwu, C. (1989). The History and Message of Islam. Awka: Meks-Unique Publishers.

Odey, D. (2012). Boko Haram: Nigeria's Path to Disintegration. In S. O. Anyanwu, \& I. U. Nwanaju (Eds.), Boko Haram and Terrorism: Religious Conflicts and Dialogue Initiatives in Nigeria (Vol. 2, pp. 48-75). Enugu: Snaap Press.

Odey, J. O. (2000). The Sharia and the Rest of Us (p. 27). Enugu: Snaap Press.

Okoro, K. (2008). Religion: A Viable Instrument of Social Reforms in a Globalized Nigeria: A Case for Islam. Nigeria Journal of Humanities and Social Sciences, 2, 215-231. 
Oladokun, V. (2015). Nigeria’s Past, Present and Future. http://www.infor@naija.com Salamone, F. A. (2007). Hausa Concepts of Muscularity and the Yan Daudu. Journal of Men, Masculinities and Spirituality, 1, 4554.

Savory, R. M. (1976). Introduction to Islamic Civilization. London: Cambridge Up.

Suberu, R. (2001). Federalism and Ethnic Conflict in Nigeria. Washington DC: USIS Press. 